Egyptian Journal of Aquatic Biology \& Fisheries

Zoology Department, Faculty of Science,

Ain Shams University, Cairo, Egypt.

ISSN $1110-6131$

Vol. 23(2): 303 - 316 (2019)

www.ejabf.journals.ekb.eg

\title{
Zooplankton groups in Lake Timsah, Suez Canal, Egypt
}

\author{
Khalied A. El-Damhougy ${ }^{1}$, Hussein A. El-Naggar ${ }^{1 *}$, Mohamed A. Aly-Eldeen ${ }^{2}$ \\ and Mohamed H. Abdella ${ }^{1}$
}

1- Zoology Department, Faculty of Science, Al-Azhar University, Cairo, Egypt

2- National Institute of Oceanography and Fisheries (NIOF), Alexandria, Egypt

* Corresponding author. Hu_gar2000@yahoo.com

\section{ARTICLE INFO}

\section{Article History:}

Received: April 17, 2019

Accepted: May 2, 2019

Online: May 12, 2019

Keywords:

Zooplankton

Distribution

Lake Timsah

Abundance

Diversity

Suez Canal

\section{ABSTRACT}

To shed some light on distribution, abundance and diversity of zooplankton groups in Lake Timsah, four cruises (spring 2015, summer 2015, autumn 2015, and winter 2016) were carried out. In the present result, Lake Timsah zooplankton were comprised 13 groups of the animal kingdom include, Copepoda (with relative abundance of 39.44\%); Rotifera $(32.72 \%)$; Mollusca (15.15\%); Tintinnida (4.55\%); Polychaeta (3.43\%); Cirripedia (1.62\%); Decapoda (1.24\%); Cladocera $(0.94 \%)$; Ostracoda $(0.57 \%)$; Appendicularia $(0.19 \%)$; Fish egg $(0.06 \%)$; Foramenifera $(0.04 \%)$ and Cnidaria $(0.04 \%)$. Copepoda was found to be the most diversified group during the study period, it represented by 62 species comprised $44.93 \%$ of the total recorded species, followed by Rotifera (33 species, $23.91 \%$ ), Tintinnida (18 species, 13.04\%), Cladocera (10 species, $7.25 \%$ ), Ostracoda (5 species, 3.62\%), Mollusca (4 species, 2.90\%), Appendicularia (3 species, $2.17 \%$ ), Cnidaria (2 species, $1.45 \%$ ) and only one species of Foramenifera represented $0.72 \%$ of the total recorded zooplankton species. Seasonally, zooplankton was flourished in summer, while winter is the lowest abundant season. Spatially, because of the difference of water masses entering the lake, each group is dominant in a certain region. Copepods are common in sites that near of Suez Canal due to the presence of saline water masses. While, rotifers and other freshwater zooplanktons are dominant in sites that near freshwater masses, such as western lagoon.

\section{INTRODUCTION}

Zooplankton is found throughout the oceans, seas and lakes of Earth and so on. However, the local abundance of plankton varies horizontally, vertically and seasonally. The primary source of this variability is the availability of light and the secondary one is the nutrient availability (Thurman, 1997). Planktonic groups may be expected to demonstrate minimal seasonal variation, with standing stocks of organisms changing only by a factor of two or three over an annual cycle (Webber and Roff, 1995). The seasonality is often unpredictable and less pronounced than in temperate waters. Annual fluctuations are generally related to shorter-term patterns of variability, for example rainfall, especially in coastal regions (Chisholm and Roff, 1990). Lake Timsah $\left(30^{\circ} 32^{\prime}\right.$ and $30^{\circ} 36^{\prime} \mathrm{N}$ latitude and $32^{\circ} 16^{\prime}$ and $32^{\circ} 21^{\prime} \mathrm{E}$ longitude) lies adjacent to Ismailia City near the middle of the Suez Canal $(80 \mathrm{~km}$ south Port Said). 
It covers about $16 \mathrm{~km}^{2}$ and its depth ranged between 3 and $16 \mathrm{~m}$. The lake is considered as one of the most productive lake along the Suez Canal (Madkour et al., 2006). At the western side, the lake is connected to a small shallow lagoon via a narrow passage. The human population of Ismailia is around 1 million. As estimated by ETPS (1995), the western lagoon receives about $833000 \mathrm{~m}^{3}$ day $^{-1}$ of domestic and agricultural waste waters from many drains (El-Mahsama, Abu-Gamouss, AbuAttwa and El-Bahtini drains). On the northern side, the lake receives occasional inputs from the Ismailia freshwater canal (Madkour et al., 2006).

Studies on the zooplankton groups of Lake Timsah are quite fragmentary when compared to other Egyptian lakes. Most of these studies were based on short-term sampling and considered the lake as one site among many along the Suez Canal (ElSerehy et al. 2000 and El-Serehy et al. 2001). Unfortunately, zooplankton groups have attracted little attention in Lake Timsah and little detailed studies have been performed in this lake (Abou-Zeid, 1990 and El-Sherbiny et al., 2011)

Hence the importance of this work is study of zooplankton groups in Lake Timsah to shed some light on diversity, distribution, abundance of their groups in this lake. Diversity indices were studied for measure the ecological "health" or stability of the zooplankton groups inhabiting the lake.

\section{MATERIALS AND METHODS}

The study area is situated at Lake Timsah. Ten stations were selected and covered all localities at Lake Timsah (Fig. 1). Zooplankton samples were seasonally collected from spring 2015 to winter 2016 by using standard plankton net $(55 \mu \mathrm{m}$ mesh size, $22.5 \mathrm{~cm}$ mouth diameter). Immediately, the collected samples were preserved in $4 \%$ neutral formalin solution. In the laboratory, the sample volume was concentrated to $100 \mathrm{ml}$ and the whole sample was examined in Petri dish to identify all groups. Triplicate of $3 \mathrm{ml}$ subsamples were transferred into a countering cell (G.F.C. rafter cell) and each group was counted under binuclear microscope. The identification of zooplankton group was done by using many keys such as, Tregouboff \& Rose (1957), Edmondson et al. (1959), Marshall (1969), Boltovskoy (1999), Conway et al., (2003) and El-Naggar (2014).

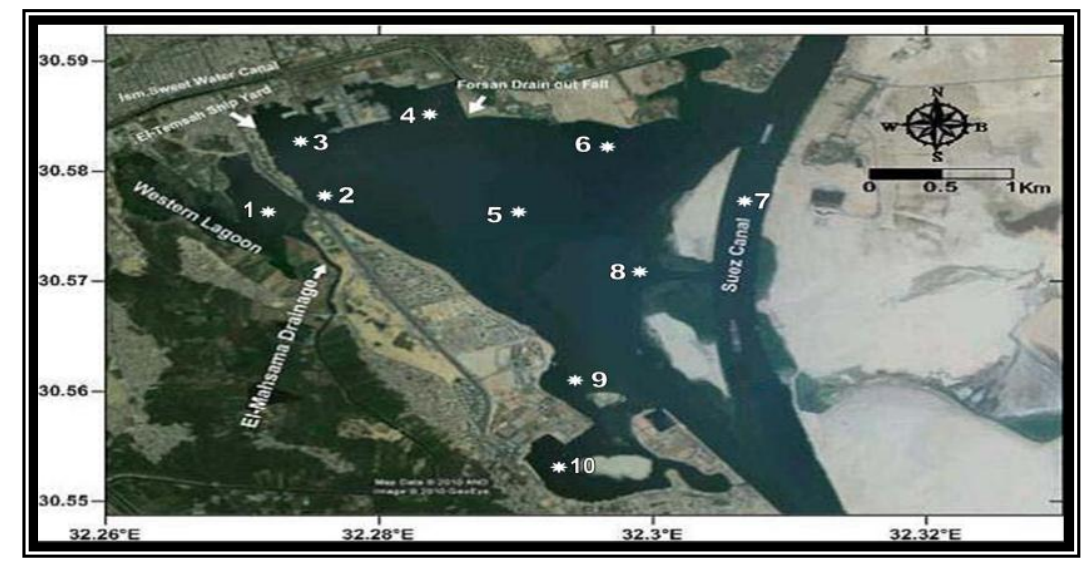

Fig. 1: A land satellite image showing the study area and the investigated stations at Lake Timsah.

Four diversity indices were calculated to estimate the stability of groups structure viz, species richness (Margalef, 1968), Shannon-Wiener diversity index (Shannon and Wiener, 1963), Evenness or equitability (Pielou, 1975), and Simpson index (Simpson, 1949). 


\section{RESULTS}

\section{Zooplankton groups composition}

The examination of zooplankton samples collected from Lake Timsah revealed that the zooplankton groups comprised 13 groups: Copepoda with relative abundance of 39.44\%; Rotifera (32.72\%); Mollusca (15.15\%); Tintinnida (4.55\%); Polychaeta (3.43\%); Cirripedia (1.62\%); Decapoda (1.24\%); Cladocera (0.94\%); Ostracoda (0.57\%); Appendicularia (0.19\%); Fish egg (0.06\%); Foramenifera $(0.04 \%)$ and Cnidaria (0.04\%). A total of 138 zooplankton taxa were identified during the present study. Copepoda was the most diversify group during the study period, they represented by 62 species comprised $44.93 \%$ of the total recorded species. Rotifera (33 species, $23.91 \%$ ) was the second diversify group, followed by Tintinnida (18 species, 13.04\%), Cladocera (10 species, 7.25\%), Ostracoda (5 species, 3.62\%), Mollusca (4 species, 2.90\%), Appendicularia (3 species, 2.17\%), Cnidaria (2 species, $1.45 \%$ ) and Foramenifera (one species, $0.72 \%$ ) (Table 1).

Table 1: Abundance, relative abundance and number of species for each group of zooplankton recorded in Lake Timsah.

\begin{tabular}{lcccc}
\hline Zooplankton groups & $\begin{array}{c}\text { Annual average } \\
\text { abundance ind./m }\end{array}$ & $\begin{array}{c}\text { Relative } \\
\text { Abundance \% }\end{array}$ & $\begin{array}{c}\text { No. of } \\
\text { species }\end{array}$ & $\begin{array}{c}\text { Percentage of } \\
\text { species No. \% }\end{array}$ \\
\hline Copepoda & 17175.01 & 39.45 & 62 & 44.93 \\
Rotifera & 14250.01 & 32.72 & 33 & 23.91 \\
Tintinnida & 1983.33 & 4.55 & 18 & 13.04 \\
Cladocera & 408.33 & 0.93 & 10 & 7.25 \\
Ostracoda & 250.00 & 0.57 & 5 & 3.62 \\
Mollusca & 6600.00 & 15.15 & 4 & 2.9 \\
Appendicularia & 83.33 & 0.19 & 3 & 2.17 \\
Cnidaria & 16.67 & 0.04 & 2 & 1.45 \\
Foramenifera & 16.67 & 0,04 & 1 & 0.72 \\
Cirripedia & 708.33 & 1.63 & 0 & 0 \\
Polychaeta & 1491.67 & 3.43 & 0 & 0 \\
Decapoda & 541.67 & 1.24 & 0 & 0 \\
Fish eggs & 25.00 & 0.06 & 0 & 0 \\
\multicolumn{1}{c}{ Total } & 43550.02 & 100 & 138 & 100 \\
\hline
\end{tabular}

Temporal distributions of the zooplankton recorded in Lake Timsah.

\section{Abundance}

The total annual average of zooplankton abundance were 43550.02 ind. $/ \mathrm{m}^{3}$. As shown in (Fig. 2) the abundance of zooplankton varies greatly from season to another. They were flourished in summer with an average of $74833.37 \mathrm{ind} . \mathrm{m}^{3}(42.95 \%$ of the total recorded zooplankton abundance), followed by spring (25.35\%), autumn (22.56 $\%$ )and winter cam at the last (9.13\% of the total recorded abundance).

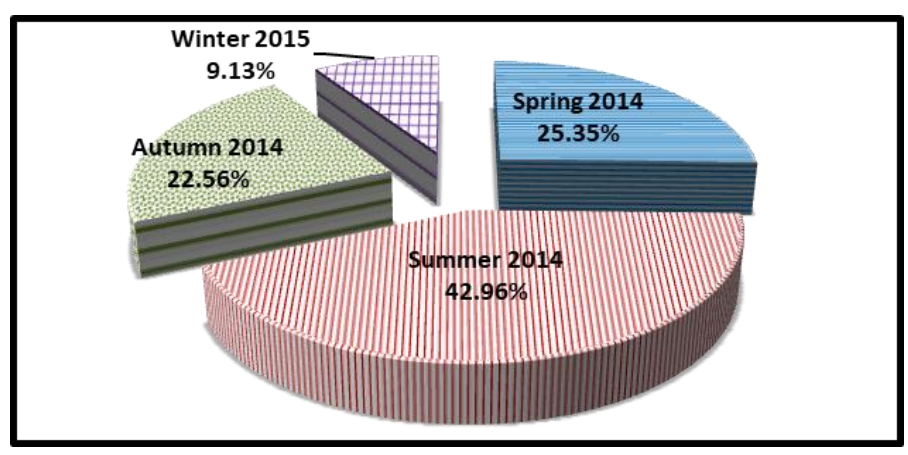

Fig. 2: The abundance (ind. $/ \mathrm{m}^{3}$ ) of recorded zooplankton in Lake Timsah during surveyed seasons. 
In this context, the variations of recorded group abundance during investigated seasons were showed that Rotifera in summer was the highest abundant group with an abundance of 34533.35 ind. $/ \mathrm{m}^{3}$, followed by Copepoda with an abundance of 25233.35 ind.$/ \mathrm{m}^{3}$, Mollusca $\left(12433.34\right.$ ind. $\left./ \mathrm{m}^{3}\right)$ and Polychaeta $\left(966.67\right.$ ind. $\left./ \mathrm{m}^{3}\right)$. During spring, copepod abundance was the highest $\left(21633.34 \mathrm{ind} / \mathrm{m}^{3}\right)$, Tintinnida was the second abundant group $\left(6433.34 \mathrm{ind} / \mathrm{m}^{3}\right)$, followed by Rotifera (4700 $\mathrm{ind} / \mathrm{m}^{2}$ ) and Mollusca (4033.33 ind $/ \mathrm{m}^{2}$ ). During autumn, Copepoda was the highest abundant group $\left(18500.01 \mathrm{ind} / \mathrm{m}^{3}\right)$, followed by Rotifera $\left(0500.01 \mathrm{ind} / \mathrm{m}^{3}\right)$, Mollusca $\left(6733.34 \mathrm{ind} / \mathrm{m}^{3}\right)$ and Polychaeta $\left(1333.33 \mathrm{ind} / \mathrm{m}^{3}\right)$. In winter, the highest group was Rotifera $\left(7266.67 \mathrm{ind} / \mathrm{m}^{3}\right)$, followed by Copepoda $\left(3333.34 \mathrm{ind} / \mathrm{m}^{3}\right)$, Mollusca (3200 $\mathrm{ind} / \mathrm{m}^{3}$ ) and Polychaeta $\left(766.67 \mathrm{ind} / \mathrm{m}^{3}\right.$ ), other groups were rare (Fig. 3).

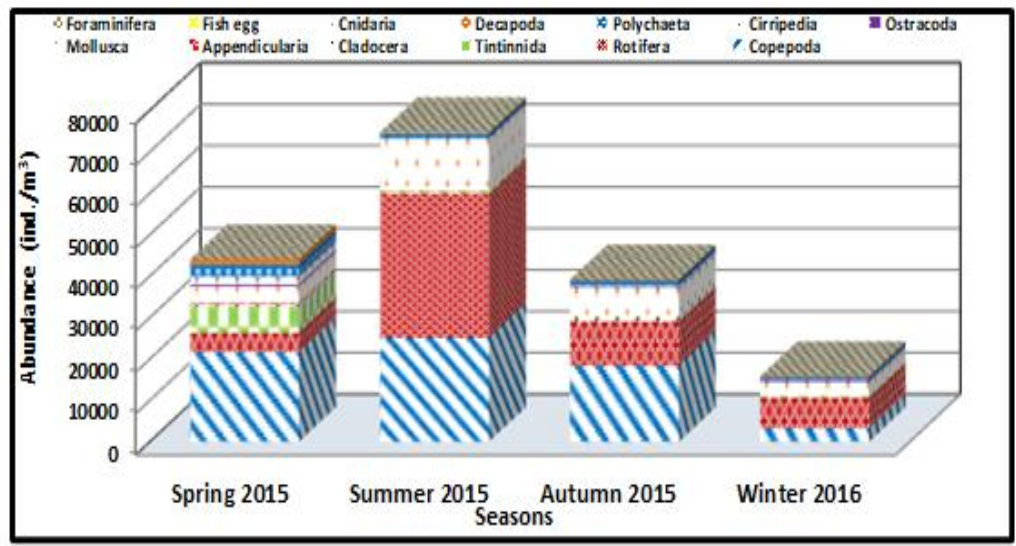

Fig. 3: The abundance of different zooplankton groups in Lake Timsah during different seasons.

\section{Number of species}

Fig. 4 shows that the number of zooplankton species was varied seasonally within wide range. From this results, the highest species number ( 83 species) was recorded in spring, followed by summer (60 species), autumn (37 species) and the lowest species number ( 24 species) were recorded in winter.

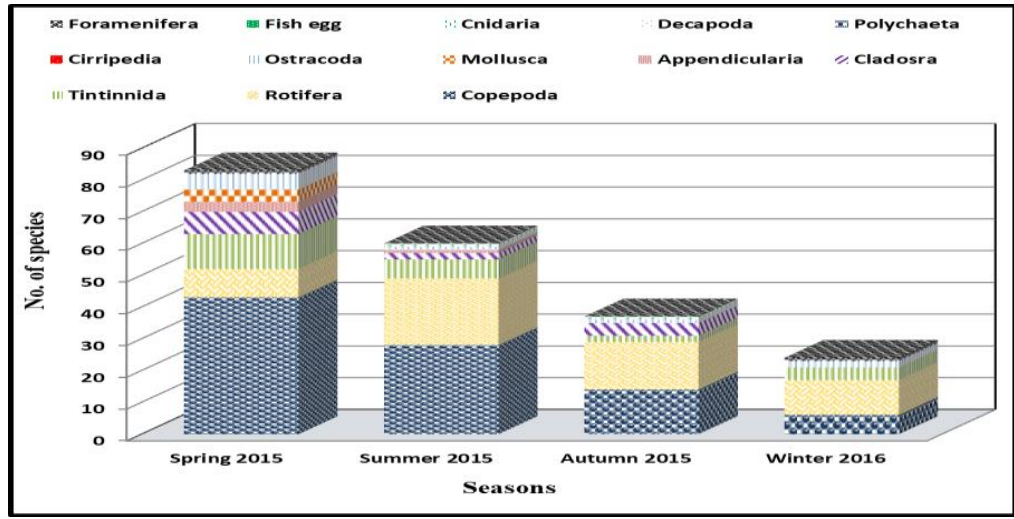

Fig. 4: Seasonal variations of number of species in different zooplankton groups in Lake Timsah.

In this context, the seasonal variations of species number of each group were explained that spring listed 43 copepod species, 11 tintinnid species, 9 rotifer species, 7 cladosran species, 5 ostracod species, 4 molluscan species, 3 appendicularian species and only one foraminiferan species. On the other hand, there are 28 copepod species, 21 rotifer species, 6 tintinnid species, 2 cladosran species and only one species of each of appendicularian, ostracod and cnidarian were recorded during summer. While, autumn noted 15 rotifer species, 14 copepod species, 4 cladosran 
species, two tintinid species and only one species of each of Ostracoda and Cnidaria. Finally, winter zooplankton were comprised of 11 rotifer species, 6 copepod species, 4 tintinid species, 2 ostracod species and only one species of Foraminifera (Fig. 4).

\section{Spatial distribution of zooplankton groups}

\section{Abundance:}

The spatial distribution of zooplankton groups at study area illustrated in (Fig. 5) and showed that the abundance was high at St.1 with an annual average of 71416.70 ind. $/ \mathrm{m}^{3}$ which represented about (16.40\% of the total abundance), followed by St.8 (52833.35 ind./. $\mathrm{m}^{3}, 12.13 \%$ ), and St.6 (52250.03 ind. $/ \mathrm{m}^{3}, 12.00 \%$ ). While,St.4, St.9 and St.3 had the lowest ones beings 29750.01, 26333.35 and $24666.67 \mathrm{ind} . / \mathrm{m}^{3}(6.83,6.05$ and $5.66 \%$ of the total abundance), respectively.

With regards of the spatial variations of recorded group abundance, copepods recorded its highest annual average of abundance at St. 6 being 32000 ind. $/ \mathrm{m}^{3}$, followed by St. $4\left(24750\right.$ ind. $\left./ \mathrm{m}^{3}\right)$, and St. $5\left(20833.3\right.$ ind. $\left./ \mathrm{m}^{3}\right)$, while it was low at St. 1 being 3250 ind. $/ \mathrm{m}^{3}$ and St. $10\left(10000\right.$ ind. $\left./ \mathrm{m}^{3}\right)$. On the other hand, rotifers abundance was high at St. 1 being (57916.7 ind./ $\left./ \mathrm{m}^{3}\right)$, followed by St. 10 (18750 ind. $\left./ \mathrm{m}^{3}\right)$, while it was low at St. $3\left(3500 \mathrm{ind} . / \mathrm{m}^{3}\right)$, and St. $5\left(5500 \mathrm{ind} . / \mathrm{m}^{3}\right)$. The molluscan abundance recorded its highest value $\left(13500\right.$ ind. $\left./ \mathrm{m}^{3}\right)$ at St. 7 , followed by $\left(13166.67 \mathrm{ind} . / \mathrm{m}^{3}\right)$ at St. 8 , while the lowest value $\left(83.33 \mathrm{ind} . / \mathrm{m}^{3}\right)$ was recorded at St. 1 and (3166.67 ind.$\left./ \mathrm{m}^{3}\right)$ at St. 4 (Fig. 5).

Tintinnids abundance was high at St. 10 being $\left(11166.67 \mathrm{ind} . / \mathrm{m}^{3}\right)$, followed by St. $8\left(2666.67\right.$ ind. $\left./ \mathrm{m}^{3}\right)$, while it low at St. 1 being $\left(83.33\right.$ ind. $\left./ \mathrm{m}^{3}\right)$. Successively, the highest polychaets abundance was recorded at St. 2 being $\left(5333.34\right.$ ind. $\left./ \mathrm{m}^{3}\right)$, followed by St. 1 (2166.67 ind. $/ \mathrm{m}^{3}$ ), while the lowest one occurred at St. 3 and St. 9 with the same average of 416.67 ind./m3. Cirripedia larvae were high abundant at St. $4\left(2000\right.$ ind. $\left./ \mathrm{m}^{3}\right)$ and low abundant at St. $6\left(166.67 \mathrm{ind} . / \mathrm{m}^{3}\right)$. In the same context, St. 2 had the highest decapods abundance $\left(1916.67\right.$ ind. $\left./ \mathrm{m}^{3}\right)$, while St. 9 had the lowest decapods abundance $\left(83.33\right.$ ind.$\left./ \mathrm{m}^{3}\right)$. Other groups (Cladoceras, Ostracoda, Appendicularia and foraminifera) were rare and recorded in few stations (Fig. 5).

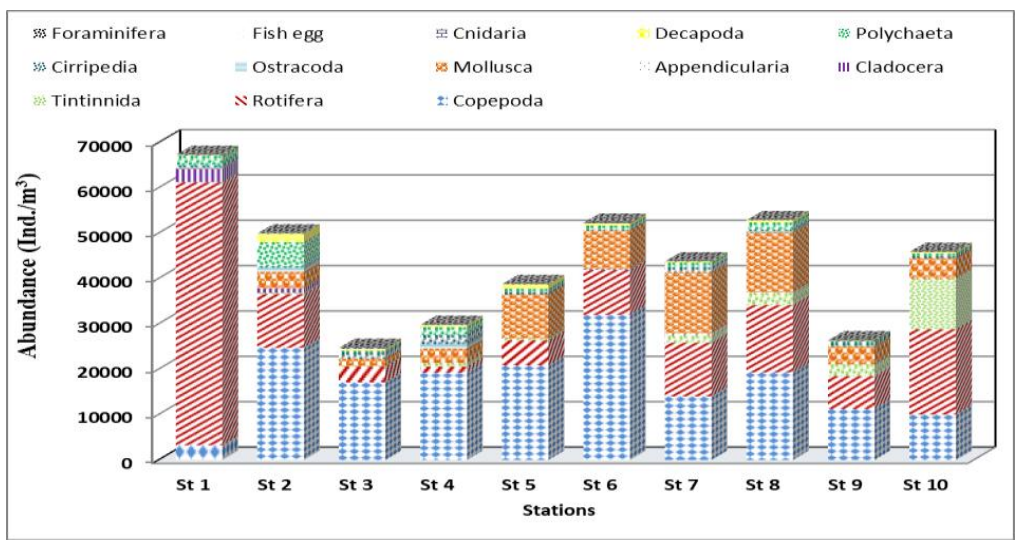

Fig. 5: The average abundance of the zooplankton recorded in different stations at Lake Timsah.

\section{Number of Species}

The spatial distribution of zooplankton species is represented in Fig. (6). St.1 was the highest station had species number of zooplankton (42 species) represented $30.4 \%$ of the total recorded species (22 rotifers species, 10 ccopepods, 5 cladocerans, 2molluscs, 2 ostracods and only one tintinnid species). St. 2 was the second station with 33 species (23.9\%) (10 copepods species, 10rotifers, 5cladosrans, 3ostracods, 3 molluscs and 2tintinnids), followed by St.8 (33 species, $23.9 \%$ ) (18 copepods species, 7 rotifers, 4 tintinnids, one of each molluscan, appendicularian, ostracod and 
forameniferan species), St.10 (33 species, 23.9\%) (17 copepods species, 9 tintinnidas and 7rotifers), St.7 (30 species, 21.7\%) (14 copepods species, 7 tintinnids, 6 rotifers and 3 appendicularians), St.5 held 29 species (21\%) (22 copepods species, 2tintinnids, 4 rotifers and only one appendicularian species), St.4 (28 species, 20\%) (14 copepods, 6 rotifers, 4 tintinnids, 2 molluscs, and only one species of Ostracoda and Appendicularia), St.9 (25species, 18.11\%) (9 copepods, 8 tintinnids, 5 rotifers and only one species of each ostracod, mollusk and cnidarian), St.6 (24 species, 17.3\%) (17 c opepods, 3 Rotifers and only one of each tintinnid, cladosran, cnidarian, forameniferan). Finally, the lowest number of species was recorded in St.3 (21 species, 15.2\%) (15 copepods species, 4 rotifers, 2 tintinnids).

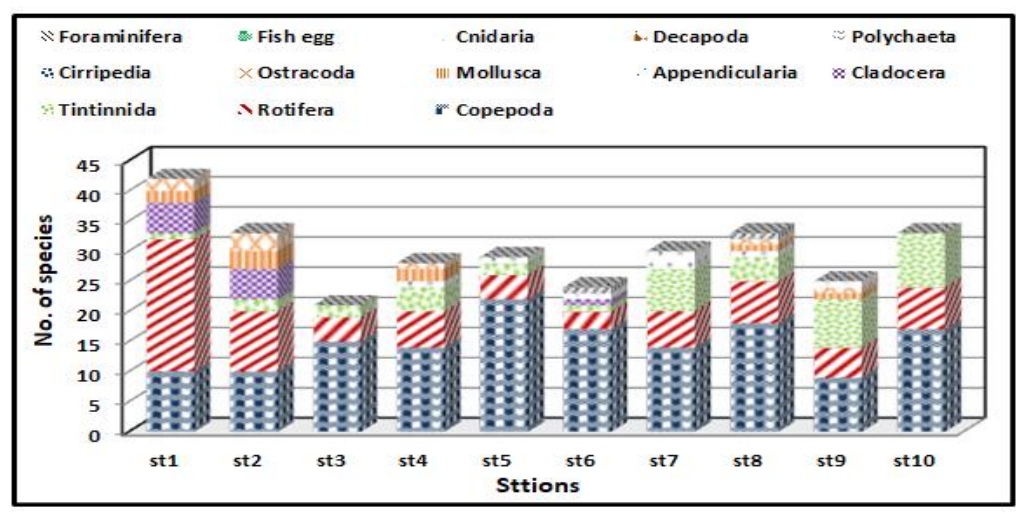

Fig. 6: Number of the zooplankton species throughout different stations at Lake Timsah

\section{Spatiotemporal distribution of zooplankton Abundance}

At all sampling stations during all surveyed seasons, zooplankton abundance show high three peaks (Fig. 7). The first peak was recorded in St.8 during summer with an abundance of 120000.06 ind. $/ \mathrm{m}^{3}$. The second peak was in St.1 during summer with an abundance of 107333.39ind. $/ \mathrm{m}^{3}$ and the third one was recorded in St.7 during summer with an abundance of 106666.72 ind. $/ \mathrm{m}^{3}$. On the other hand, the smallest values of abundance occurred in St.3 during winter (3000 ind. $/ \mathrm{m}^{3}$ ), St.4 during winter $\left(5666.67\right.$ ind. $/ \mathrm{m}^{3}$ ) and St.7 and St.10 during winter with an abundance for each one of $9666.67 \mathrm{ind} . / \mathrm{m}^{3}$.

According to the present data, copepod abundance was fluctuated between the low value $\left(1000\right.$ ind. $\left./ \mathrm{m}^{3}\right)$ at each of St.3 and St.9 during winter and high value (54000 ind. $/ \mathrm{m}^{3}$ ) at St.4 during spring. On the other side, the low value of rotifers abundance $\left(333.33 \mathrm{ind} / \mathrm{m}^{3}\right.$ ) was recorded in each of St.7 during spring and St.5 during autumn, while the high value $\left(99666.72\right.$ ind. $\left./ \mathrm{m}^{3}\right)$ were recorded in St.1 during summer. Tintinnids abundance was ranged between lowest abundance at many stations, and highest abundance at St.10 during spring being 44333.35 ind. $/ \mathrm{m}^{3}$. Cladoceran recorded its lowest abundance (333.34 ind $/ \mathrm{m}^{3}$ ) at St.2 during autumn, while its highest one $\left(9333.34\right.$ ind $\left./ \mathrm{m}^{3}\right)$ happened at St.1 during autumn. Appendicularians had low abundance $\left(333.34 \mathrm{ind} . / \mathrm{m}^{3}\right)$ at St.4 during spring and St.5 during summer, but the high value $\left(2000 \mathrm{ind} . / \mathrm{m}^{3}\right)$ was noticed at St.7 during spring. Successfully, the abundance of molluscans ranged between low value of 333.33 ind. $/ \mathrm{m}^{3}$ at St. 3 and St. 4 during winter, and high value of 35333.35 ind. $/ \mathrm{m}^{3}$ at St.7 during summer. On the other side, Ostracods recorded the lowest abundance (333.33 ind. $/ \mathrm{m}^{3}$ ) at St. 1 during summer and St.9 during winter, while the highest one (2666.6 ind./m3 ) was recorded at St.4 during winter. Cirriped larvae recorded its lowest abundance $\left(333.33\right.$ ind.$/ \mathrm{m}^{3}$ ) at many stations and highest abundance $\left(6666.67 \mathrm{ind} . / \mathrm{m}^{3}\right)$ 
at St.4 during spring. The low abundance of polychaets $\left(333.33\right.$ ind. $\left./ \mathrm{m}^{3}\right)$ was recorded at many stations and the high abundance $\left(16000\right.$ ind. $\left./ \mathrm{m}^{3}\right)$ was recorded at St.2 during spring. Plnktonic decapods larvae were recorded its lowest abundance (333.33 ind.$\left./ \mathrm{m}^{3}\right)$ during many stations, while the highest abundance $\left(7000\right.$ ind.$\left./ \mathrm{m}^{3}\right)$ was recorded at St.2 during spring. Cnidarians, fish eggs and forameniferans were very rare and seen little times only during study period (Fig.7).

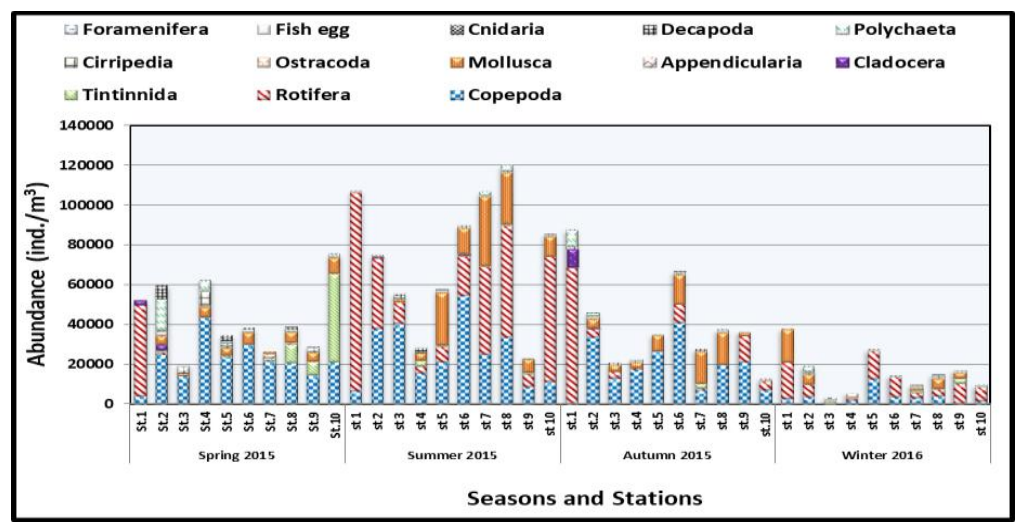

Fig.7: The Abundance (ind. $/ \mathrm{m}^{3}$ ) of the zooplankton groups recorded in different stations of Lake Timsah during study period.

\section{Number of Species}

The number of zooplankton species recorded its highest value (22 species) at St.7 during summer, followed by 20 species at St.7 during spring and 19 species at St.1 during spring, but the lowest number of species (3 species)was recorded in each of St.3 during winter, St.3 and St.9 during autumn, and 4 species at St.10 during winter (Fig. 8),

Regarding groups, the highest number of copepod species (14 species) was recorded at St.5 during spring, followed by 13 species at St.4 during spring and St.8 during summer, while the lowest one (one species) was recorded at St.3, St.7 and St.10 during winter. In this context, the number of rotifers species was high at St.1 during autumn being 11 species, while the lowest one (one species) was occurred at St.7 during spring and each of St.3, St.5, St.6, St.9 and St.10 during autumn.

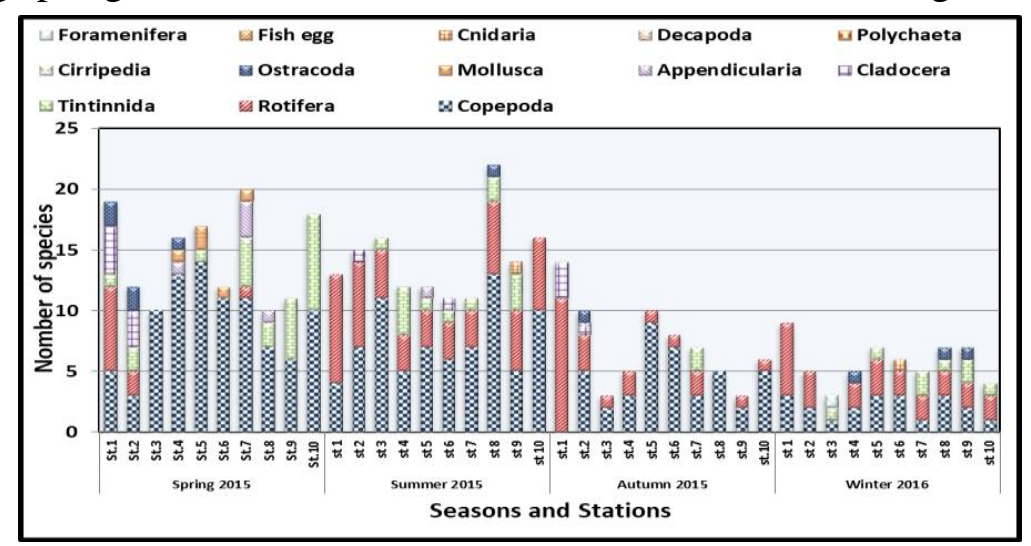

Fig. 8: The number of zooplankton species recorded throughout different stations at Lake Timsah during study period.

On the other hand, the number of tintinnid species was high (8 species) at St.10 during spring, while its lowest value (one species) was recorded at many stations during different season. The number of cladosran species was high (4 species) at St.1 during spring, and low (one species) at St.2 and St.6 during summer and St.2 during autumn. 
The highest number of appendicularian species ( 3 species) was recorded in St.7 during spring. The highest number of molluscan species ( 2 species) was noted in St.5 during spring. While, the number of ostracod species was high (2 species) at St.1 and St.2 during spring. Finally, there is only one cnidarian species were seen only one time (Fig 8).

\section{Stability of zooplankton distribution in Lake Timsah: Temporal stability.}

The present data showed that zooplankton species were unstable in their temporal distribution, where $71.74 \%$ of zooplankton species were recorded in one season only, $14.49 \%$ in two seasons, $9.42 \%$ in three seasons and $4.35 \%$ of recorded species were frequented in four seasons (Fig. 9).

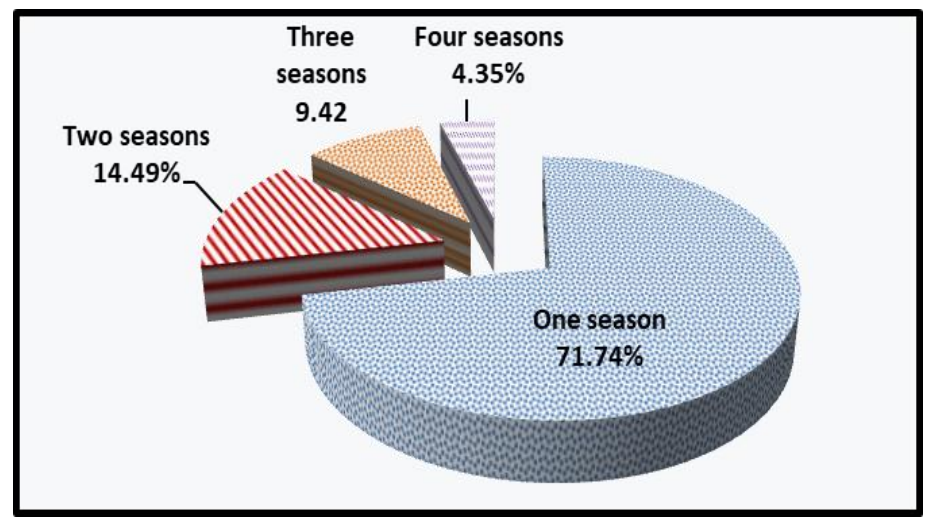

Fig. 9: The stability of zooplankton distribution in Lake Timsah on temporal scale.

\section{Spatial stability}

It is clear from Figure (10), the zooplankton species were poorly distributed between investigated stations, where $56.52 \%$ of the total zooplankton species were recorded in one station, $21.01 \%$ in two stations, $7.97 \%$ in three stations, $4.35 \%$ in four stations, $2.17 \%$ in five stations, $2.17 \%$ in six stations, $1.45 \%$ in seven stations, $1.45 \%$ in eight stations, $0.72 \%$ in nine stations and $2.17 \%$ ten stations.

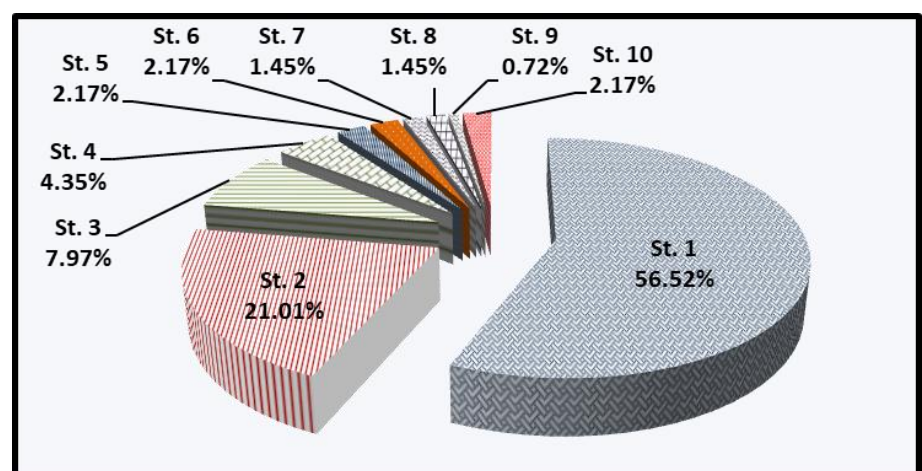

Fig. 10: The stability of zooplankton distribution in Lake Timsah on spatial scale.

\section{Diversity indices of zooplankton distribution in Lake Timsah}

As a result of the Table (2), the ecological diversity indices are fluctuated within wide range between stations during four seasons. Where, the highest value of species richness (1.909) was recorded in St. 7 during spring, followed by, 1.863 in St. 8 during summer, while its lowest value (0.2003) occurred in St. 9 during autumn followed by, 0.2085 in St. 3 during autumn. Also, the highest value of Shannon index (2.465) was recorded in St. 7 during spring, followed by 2.121 in St. 9 during summer, but its lowest value (0.6722) was recorded in St. 6 during winter, followed 
by 0.7309 in St. 6 during winter. In this context, the highest Evenness values are 0.964 and 0.946 in St. 3 during autumn and winter, respectively. But, the lowest Evenness values were 0.405 and 0.2873 at St. 1 during spring and summer, respectively. Concerning the Simpson index, its highest value was 0.8809 and 0.8577 at St. 7 during spring and St. 1 during autumn, respectively. While, its lowest value was recorded in 0.2766 in St. 1 during spring, followed by 0.2979 at St. 6 during winter.

Table 2: The Diversity indices for zooplankton species inhabiting Lake Timsah.

\begin{tabular}{|c|c|c|c|c|c|}
\hline Seasons & Stations & $\begin{array}{l}\text { Species } \\
\text { richness }\end{array}$ & Eveness index & Shannon index & Simpson index \\
\hline \multirow[t]{10}{*}{ Spring 2015} & St. 1 & 1.661 & 0.2873 & 0.8459 & 0.2766 \\
\hline & St. 2 & 1.121 & 0.8476 & 2.106 & 0.8457 \\
\hline & St. 3 & 0.9582 & 0.898 & 2.068 & 0.8473 \\
\hline & St. 4 & 1.426 & 0.6858 & 1.901 & 0.7892 \\
\hline & St. 5 & 1.613 & 0.7414 & 2.101 & 0.7998 \\
\hline & St. 6 & 1.075 & 0.6866 & 1.706 & 0.7644 \\
\hline & St. 7 & 1.909 & 0.8228 & 2.465 & 0.8809 \\
\hline & St. 8 & 0.8876 & 0.8321 & 1.916 & 0.8148 \\
\hline & St. 9 & 1.038 & 0.8016 & 1.922 & 0.812 \\
\hline & St. 10 & 1.545 & 0.7303 & 2.111 & 0.8222 \\
\hline \multirow{10}{*}{ Summer 2015} & St. 1 & 0.9538 & 0.4052 & 1.007 & 0.4424 \\
\hline & St. 2 & 1.267 & 0.6467 & 1.751 & 0.7614 \\
\hline & St. 3 & 1.416 & 0.6066 & 1.682 & 0.6756 \\
\hline & St. 4 & 1.129 & 0.83 & 2.062 & 0.8397 \\
\hline & St. 5 & 1.091 & 0.8 & 1.988 & 0.8218 \\
\hline & St. 6 & 0.9271 & 0.6517 & 1.563 & 0.7097 \\
\hline & St. 7 & 0.9103 & 0.697 & 1.671 & 0.7554 \\
\hline & St. 8 & 1.863 & 0.6806 & 2.104 & 0.798 \\
\hline & St. 9 & 1.358 & 0.8037 & 2.121 & 0.8329 \\
\hline & St. 10 & 1.346 & 0.6437 & 1.785 & 0.769 \\
\hline \multirow[t]{10}{*}{ Autumn 2015} & St. 1 & 1.155 & 0.7953 & 2.099 & 0.8577 \\
\hline & St. 2 & 0.8642 & 0.6459 & 1.487 & 0.6596 \\
\hline & St. 3 & 0.2085 & 0.9644 & 1.059 & 0.6405 \\
\hline & St. 4 & 0.4115 & 0.553 & 0.89 & 0.4776 \\
\hline & St. 5 & 0.8853 & 0.6377 & 1.468 & 0.6381 \\
\hline & St. 6 & 0.7736 & 0.6104 & 1.341 & 0.6526 \\
\hline & St. 7 & 0.6708 & 0.8597 & 1.673 & 0.7827 \\
\hline & St. 8 & 0.4431 & 0.8194 & 1.319 & 0.6785 \\
\hline & St. 9 & 0.2003 & 0.6653 & 0.7309 & 0.4848 \\
\hline & St. 10 & 0.5538 & 0.7007 & 1.256 & 0.6177 \\
\hline \multirow[t]{10}{*}{ Winter 2016} & St. 1 & 0.8092 & 0.4331 & 0.9515 & 0.3838 \\
\hline & St. 2 & 0.4431 & 0.842 & 1.355 & 0.7041 \\
\hline & St. 3 & 0.278 & 0.9464 & 1.04 & 0.6255 \\
\hline & St. 4 & 0.4735 & 0.7784 & 1.253 & 0.6226 \\
\hline & St. 5 & 0.609 & 0.5349 & 1.041 & 0.4808 \\
\hline & St. 6 & 0.4259 & 0.4176 & 0.6722 & 0.2979 \\
\hline & St. 7 & 0.4598 & 0.8623 & 1.388 & 0.7223 \\
\hline & St. 8 & 0.6708 & 0.7947 & 1.546 & 0.7222 \\
\hline & St. 9 & 0.6351 & 0.6175 & 1.202 & 0.5624 \\
\hline & St. 10 & 0.3323 & 0.7359 & 1.02 & 0.5761 \\
\hline
\end{tabular}

\section{DISCUSSION}

Zoogeography plays an important role in determining zooplankton species distribution on a broad scale (Keller and Pitblado, 1989).Zooplankton has a nonrandom distribution in the pelagic groups and exhibits various levels of patchiness (Haury et al., 1978). The distribution of zooplankton species may be determined seasonally, spatially or geographically by one or more of a number of limiting factors (Goldman and Heron, 1983). The zooplankton distribution in Lake Timsah has received little attentions in the past decade in regards to its importance as a rout in 
zooplankton migration between Mediterranean Sea and Red Sea (Zakaria et al, 2016, 2018a).

In over view of the present result, the zooplankton groups collected from Lake Timsah comprised 13 groups have a total of 138 species and immature stages and larvae.The number of zooplankton species recorded in the present study is very higher than that recorded in the previous studies by Abou-Zeid (1990) (37 taxa) and El-Sherbiny et al. (2011) (34 species). The great varieties in the number of zooplankton species between the present result and the previous ones were attributed to many reasons include; the difference of studied stations; period and mode of collection, mesh size of collecting zooplankton net and climatic changes. Different method of collection yielded different result as investigated by Abd El-Rahman (2005).

In general, the present huge number of species recorded in the lake can be attributed to the continuous discharge of wastewater, which leads to increasing nutrient concentrations in the lake and western lagoon. In addition, Lake Timsah is continuously showing alternative changing in its water characters, because it usually receives high salinity waters from the Great Bitter Lake in the south and these are overlined by a layer of fresh and brackish water coming into the lake from the outflow of Ismailia freshwater canal; in addition to fresh water from four drains: ElMahsama, EI-Bahtini, Abu-Gamous and El-Forsan. These salinity variations create different habitats for more different species. Environmental salinity is a major factor in reproduction, larval dispersal and recruitment, geographical distribution, and behavior of marine species (Spivak and Cuesta, 2009 and Smyth et al., 2014). Because of this, salinity changes will influence the structure of groups and the boundaries of species distribution inside lake.

The total zooplankton density during the investigation period revealed that the zooplankton standing crop in Lake Timsah (43550.02ind./m3) were more productive than the previous studies, El-Sherbiny et al. (2011) showed an annual average zooplankton density of $22026 \mathrm{ind} . / \mathrm{m}^{3}$ and Abou-Zeid (1990) recorded $23419 \mathrm{ind} . / \mathrm{m}^{3}$. Also, these values indicated that the lake is less productive than other Egyptian lakes such as; Lake Buroullus (183000 ind./m³) during 1987 (Aboul-Ezz 1995), Lake Maryout with approximately 117000 ind./m³ during 1996-1997 (Abdel-Aziz andAboul-Ezz 2004), Lake Idku with 326000 ind./m³ during 2000 (Aboul-Ezz and Soliman, 2000); 50355.2ind. $/ \mathrm{m}^{3}$ (Sharaf, 2018) and Lake Manzalah with $5 \times 10^{6}$ ind. $/ \mathrm{m}^{3}$ (El-Sherif et al. 1994).

In concerning of temporal distribution of zooplankton, summer was the most productive season, but the minimum densities were recorded in winter. This pattern of temporal distribution was confirmed by El-Sherbiny et al. (2011) at this Lake. In contrast, El-Bassat (2008)find opposite the present result in Bitter Lakes; who stated that autumn is the more productive season and spring and summer the poorest ones. In the context of the variations of number of zooplankton species during study period, spring has the highest diversity and the winter was the lowest. Zooplankton distribution and dynamics in estuaries are driven by physical -chemical factors, biological characteristics, meteorological conditions and the interactions of these factors (Telesh, 2004). The presence of high densities in these seasons may also be due to the breeding season of these species. This is comparable with the studies of Abou-Zeid (1990) in the same area and Hanafy et al. (1998) in the mangrove area in the Gulf of Aqaba.

According to the data of spatial distribution, the abundance of zooplankton species was high in freshwater at western lagoon followed by the saline water 
stations near Suez Canal. Also, the number of species was high in freshwater at western lagoon then the species spread almost equally between the other study stations. The differences in salinity, changes in the water characteristics and the variations of the water masses that the lake receives them are working to change of the zooplankton distribution within the lake. Where, the stations close to the nonmixed water masses, such as the Western Lagoon station and high salinity stations near the Suez Canal contain semi-stable groups, and have species coexist and adapt with their optimum habitat, so increase their abundance. on the other side, they when moving toward the high mixing stations in the middle of the lake, they trying to adapt, and could be affected by the changes in these stations. In this context, most individuals can't cope on these changes and lead to reducing their abundance, while some individuals trying to resist the changes. This explains the semi-homogenous distribution of species and decreasing of their abundance in these stations. This is confirmed by the instability in the distribution of species, whether on the temporal or spatial scale. Where on a temporal scale, there are more than $71 \%$ of the species were recorded in only one season whereas on the spatial scale, there are more than $56 \%$ of the species were recorded in one stations. The temporal and spatial distribution of zooplankton differs according to the controlling factors. Siebeck (1980) mentioned that zooplankton is not only regulated in their distribution by the physical factors; they swim both vertically and horizontally.

Changes in the abiotic environment can have wide-ranging biological effects among them population-level shifts of distribution due to physiological intolerance to new conditions (Bernhardt and Leslie, 2013). These shifts can result in changes in groups structure and species interactions which have the potential to influence ecosystem functioning and the provision of services to society (Doney et al., 2012).Changes in environmental stressors can influence the distribution of species and assemblages, the timing of important life-cycle events, abundance and groups structure (Moller et al., 2015). Zooplankton groups are highly sensitive to environmental variation. As a result, changes in their abundance, species diversity, or groups composition can provide important indications of environmental change or disturbance. They respond to a wide variety of disturbances including nutrient loading (Dodson 1992), acidification (Marmorek and Kormann, 1993), contaminants (Yan et al., 1996), fish densities (Carpenter and Kitchell, 1993), and sediment inputs (Cuker, 1997).

In concerning of the diversity indices that use as a measure of ecological "health" or stability of the biotic groups. Also, the species indices values resulting from the present data confirm and indicate to the species disturbance between stations during study period. (Bojanic et al., 2012) found that the species richness (S) was positively related to overall zooplankton abundance on a temporal scale, but the strength of that relation was negatively related to increased trophic state. Zooplankton abundance and species dominance increased proportionally with increased trophic state. They concluded that species richness was positively related to overall abundance temporally and was also affected by environmental trophic state.

Because the difference of water entering the lake, it is clear that each group dominant a region. Where, copepods were common in stations that near of the Suez Canal due to the presence of saline water masses. Whereas, rotifers were dominant in stations near freshwater masses, such as Western Lagoon. Specially, Copepods represented the subdominant component, followed by rotifers, Tintinnida.,Cladocera and Ostracoda. This finding resembles that recorded by El-Sherbiny et al. (2011) in 
the same Lake. They stated that the high abundance of copepods in Lake Timsah occurred under conditions of elevated salinity, whereas lower salinity allowed rotifers and other freshwater forms to flourish near the outlet of a canal carrying urban waste. This dominance of copepods was documented previously in the same area (Abou-Zeid 1990; Ghobashy et al. 1992), in the Suez Canal area (El-Serehy et $a l ., 2001$ ) and in the eastern Mediterranean (Dowidar, 1988; Zakaria et al., 2018b). Rotifers are known to be excellent indicators of organic pollution as they thrive better in organically rich environments (Paleolog et al., 1997). A comparative investigation of Egyptian lagoons showed that cleaner environments have smaller standing crops and are not so species-rich, whereas eutrophic areas sustain the greatest number of both individuals and species, though only up to a certain level (Guerguess, 1992). Rotifers constituted the second most important group, they were found in high densities at sites of low salinity which receive polluted water from agricultural drainage as well as domestic sewage (ETPS, 1995), but were practically absent in the middle of the lake and near Suez canal. The high densities of mollusc and polychaete larvae reflect their great contribution and the dominance of these groups in the lake (Ghobashy et al., 1992; Kandeel 1992).

\section{REFERENCES}

Abd El-Rahman, N. S. (2005). The immigration progress of planktonic copepoda across the Suez Canal, Egypt. Egy. J. Aquat. Biol. Fish., 9(3): 59-82.

Abdel-Aziz, N. E. and Aboul-Ezz, S. M. (2004). The structure of zooplankton groups in Lake Maryout, Alexandria, Egypt, Egy.. J. Aquat. Res., 30(A): 160-1.

Aboul-Ezz, S. M. (1995). Zooplankton of Lake Buroullus, Bull. Nat. Inst. Oceanogr.Fish. Egy, 2 (11): 233-261.

Aboul-Ezz, S. M. and Soliman, A. M. (2000). Zooplankton groups in Lake Edku, Bull. Nat. Inst. Oceanogr. Fish. 26: 71-99.

Abou-Zeid, G. M. (1990). Distribution of zooplankton in Lake Timsah with special reference to Copepoda, M. Sc. thesis, Fac. Sci. Suez Canal Univ., pp. 96.

Bernhardt, J. R. and Leslie, H. M. (2013). Resilience to climate change in coastal marine ecosystems. The Annual Review of Marine Science, doi, 10.1146/annurev-marine121211-172411., 371-392

Bojanic, N .; Vidjak, O.; Solić, M.; Krstulovic, N.; Brautovic, I.; Matijevic, S.; Kuspilic ,G.; Sestanovic, S.; Gladan, Z. N. and Marasovic, I. (2012). Groups structure and seasonal dynamics of tintinnid ciliates in Kaštela Bay (middle Adriatic Sea). Res. 35 (12): 3723-3733.

Boltovskoy, D. (1999). South Atlantic Zooplankton. Backhuys Publishers, Leiden, the Netherlands, $1 \& 2: 1706 \mathrm{p}$.

Carpenter, S. R. and J. F. Kitchell. (1993). The trophic cascade in lakes. Cambridge University Press. Cambridge, U.K.

Chisholm, L. A. and Roff, J. C. (1990). Size-weight relationships and biomass of tropical neritic copepods off Kingston, Jamaica. J. of Mar. Biol., 106(1): 71-77.

Conway, D.V.P.; White, R.G.; Hugues-Dit-Ciles, J.; Gallienne, C.P. and Robins, D.B. ( 2003). Guide to the coastal and surface zooplankton of the south-western Indian Ocean, Vol. Occasional Publ. No. 15. Mar. Biol. Asso. of the U.K..

Cuker, B. E. (1997).Field experiment on the influence of suspended clay and P on the plankton of a small lake. Limnology and Oceanography 32: 840-847

Dodson, S. (1992). Predicting crustacean zooplankton species richness. Limnology and Oceanography 37: 848-856. 
Doney, S. C.; Ruckelshaus, M.; Duffy, J. E.; Barry, J. P.;Chan, F English, C. A.; Galindo, H. M.; Grebmeier, J. M. et al. (2012). Climate change impacts on marine ecosystems. Annu. Rev. Mar. Sci., 4:11-37.

Dowidar, N. M. (1988). Productivity of the south-eastern Mediterranean. In: M.I. ElSABH \& T.S. MURTY (Ed.), Nat. and man-Made Hazards

Edmondson, W.T.; Ward, H.B.; and Whipple, G.C. ( 1959). Fresh water biology, 2nd ed. John Wiley and Sons Ins. New York and London, XX, 1248p

El-Bassat, A. R. ( 2008).Composition and abundance of the zooplankton groups in the Bitter Lakes, Egypt, in relation to environmental factors. African J. of Aquatic Science, 33(3): 233-240.

El-Serehy, H.; Aboul-Ezz , S.; Samaan, A.and Abdel-Rahman N. (2000). Zooplankton groups, their distribution and relationship to environmental variables in the Suez Canal ecosystem, J. Egypt. Ger. Soc. Zool., 32 (D), 85-101.

El-Serehy, H.; Aboul-Ezz, S.; Samaan A.and Saber N. (2001). On the ecological role of Copepoda in the Suez Canal marine ecosystem, Egypt. J. Biol., 3, 116-123.

El-Sherbiny, M.M.;Al-Aidaroos, A.M. and Gab-Alla, A.( 2011). Seasonal composition and population density of zooplankton in Lake Timsah, Suez Canal, Egypt. Oceanologia, 53: 837-859. https:// doi.org/10.5697/oc.53-3.837

El-Sherif, Z.M.; Aboul-Ezz, S.M.and El-Komi M.M. (1994). Effect of pollution on the productivity in Lake Manzalah, Egypt, Int. Conf. 'Future Aquatic Resources in Arab Region., 159-169.

ETPS. ( 1995). Environmental testing of pollution status in Lake Timsah, Ismailia Egypt, Sustain. Ismailia Proj., Abu-Attwa Water Reuse Ctr. Train., 356 pp.

Ghobashy, A. F.A.; Mohammed, S. Z.; Sharaf, G.M.; El-Komi, M.M. (1992). Zooplankton of Lake Timsah Suez Canal, 2 - Copepoda, J. Egypt. Ger. Soc. Zool., 7 (B): 207-222.

Goldman, C.R. and Heron, A.J. (1983). Limnology McGraw-Hill, New York, 464p. induced mortality. J. Plank. Res., 14: 1331-1342.

Guerguess, S.K. (1992). Planktonic rotifers as indicators of pollution in Mediterranean coastal lagoons of Egypt, Rapp. Comm. Int. Mer. Medit‘. pp. 33, 95.

Gurney, R. (1932) .The British freshwater copepoda (Harpacticoida) Vol. 2 Ray Soc., London, 336p.

Gurney, R. (1933).The British Freshwater copepods (Cyclopoida) Vol. 3 Ray Society London, 484p.

Hanafy, M.H.; Dorgham, M.M.and El-Sherbiny M.M. (1998). Zooplankton groups in the Mangal ecosystem in Sharm El-Sheikh coast, Red Sea, J. Aquat. Biol. Fish., 2 (4):465-482.

Haury, L.R.; McGowan, J.A. and Wiebe, P.H. (1978). Patterns and processes in the time-space scale of plankton distributions. In Steele JH (Ed.).Spatial Pattern in Plank. Comm. Plenum, New York, 277-327 p.

Kandeel, K.E. (1992). Biological studies on the reproduction of some bivalves in Lake Timsah, M. Sc. thesis, Suez Canal Univ.

Keller, W. and Pitblado, J.R. (1989). The distribution of crustacean zooplankton in northeastern Ontario, Canada. J. Biogeogr., 16: 249-259.

Madkour, F.; Aamer, M.and El-Sherbiny M.( 2006). Assessment of eutrophication in Lake Timsah, Suez Canal, Egypt, Egypt. J. Aquat. Res., 32 (Spec. iss.), 259-272.

Margalef, R. (1968). Perspectives in Ecological Theory. Univ. of Chicago Press, Chicago, IL, 111pp.

Marmorek, D.R. and J. Korman. (1993). The use of zooplankton in a biomonitoring program to detect lake acidification and recovery. Water, Air, and Soil Pollution 69: 223-241. 
Marshall, S.M. (1969). Protozoa, order Tintinnia. Fiches d'indentification de Zooplancton.ConseilInternat.pourl'Exploration de la Mer, Copenhagen, pp. 117127.

Moller, K.O.; Schmidt, J.O.; John, M.S.; Axeltemming, Diekmann, R; Peters, J.; Floeter, J.; Sell, A.F.; Herrmann, J. and Mollmann, C.( 2015). Effects of climateinduced habitat changes on a key zooplankton species. J. Plankton Res. (2015) 37(3): 530-541.

Paleolog, A.; Radwan, S.; Kowalik, W.; Kowalczyk, C.; Stryjecki, R.; Zwolski, W.(1997).Water invertebrates in Janowski forests landscape park, [in:] Environment of Janowski forests landscape park, UMCS Publ., Lublin, 117-133.

Pielou, E.C. (1975).Ecological diversity. John Wiley and Sons, New York.

Shannon CE, Weaver, W. (1963).The mathematical theory of communications. University Illinois, Urbana, p 117

Sharaf, M. B. (2018). Monitoring the physico-chemical and eutrophication conditions in Lake Edku and its impact on abundance and diversity of zooplankton. M.Sc. Thesis, Fac. Sci., Al-Azhar Univ. Egypt, 220 PP.

Siebeck, H. O. (1980). Optical orientation of pelagic crustaceans and its consequence in the pelagic and littoral zones. Univ. press of New England, Hanover, New Hampshire, 28-38p.

Simpson, E.H. (1949). Measurement of diversity. Nature 163, 688.

Smyth, K.; Mazik, K. and Elliott, M. (2014). Behavioural effects of hypersaline exposure on the lobster Homarus gammarus (L) and the crab Cancer pagurus (L). Journal of Experimental Marine Biology and Ecology., 457: 208-214.

Spivak, E. D. and Cuesta, J. A. (2009).The effect of salinity on larval development of Ucatangeri (Eydoux, 1835)(Brachyura: Ocypodidae) and new findings of the zoeal morphology. Scientia Marina., 73(2): 297-305.

Telesh, I. V. (2004). Plankton of the Baltic estuarine ecosystems with emphasis on Neva Estuary: a review of present knowledge and research perspectives. Marine Pollution Bulletin., 49(3):206-219.

Thurman, H.V. (1997).Introductory Oceanography. New Jersey, USA: Prentice Hall college.

Tregouboff, G. and Rose, M. (1957).Manuel de planctologieMediterraneenne. I (Texte); 587 pp. 2(Fig.): 207 pI. C. N. R. S., Paris.

Webber, M.K.and Roff, J.C. (1995). Annual structure of the copepod groups and its associated pelagic environment off Discovery Bay, Jamaica. Mar. Biol., 123: 467 479. :

Yan, N.D.W.; Keller, K.M.; Somers, T.W.; Pawson, and R.E. Girard.( 1996). Recovery of crustacean zooplankton groups from acid and metal contamination: comparing manipulated and reference lakes. Canadian Journal of Fisheries and Aquatic Sciences 53: 1301-1327.

Zakaria, H.Y.; Hassan, A.M.; El-Naggar, H.A. and Abou-Senna, F.M. (2016). Abundance, distribution, diversity and zoogeography of epipelagic copepods off the Egyptian Coast (Mediterranean Sea). Egyptian Journal of Aquatic Research. 42(4): 459-473.

Zakaria, H.Y.; Hassan, A.M.; El-Naggar, H.A. and Abou-Senna, F.M. (2018a). Planktonic protozoan population in the Southeastern Mediterranean off Egypt. Egyptian Journal of Aquatic Research. 44: 101-107.

Zakaria, H.Y.; Hassan, A.M.; El-Naggar, H.A. and Abou-Senna, F.M. (2018b). Biomass determination based on the individual volume of the dominant copepod species in the Western Egyptian Mediterranean Coast. Egyptian Journal of Aquatic Research, 44: 89-99. 


\title{
ARABIC SUMMARY
}

\section{مجاميع العوالق الحيوانية في بحيرة التمساح، قناة السويس، مصر \\ خالد عبد اللطيف الدمهوجي'، حسين عبد المجيد النجار "، محمد عبد النبي علي الدين ؛، محمد حلمي عبد الله}

\author{
1 ـ قسم علم الحيوان، كلية العلوم، جامعة الأزهر، القاهرة، مصر

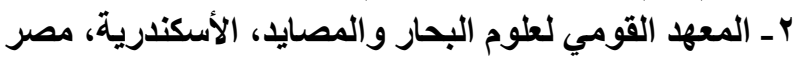

لإلقاء الضوء على توزيع وفرة وتنوع مجمو عات العو الق الحيو انية في بحيرة التمساح، تم تتفيذ أربع رحلات حقلية للبحيرة

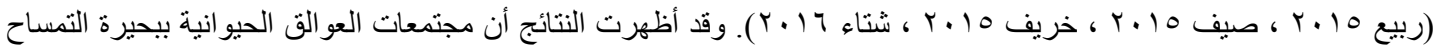

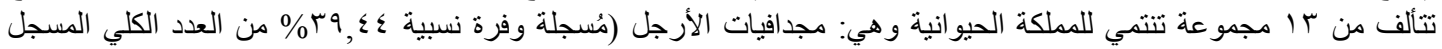

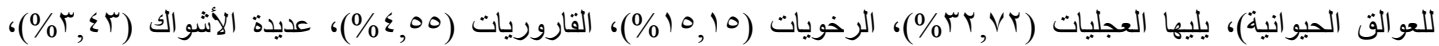

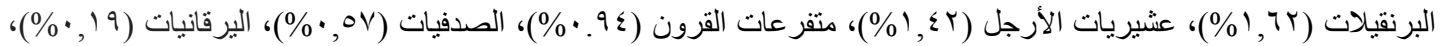

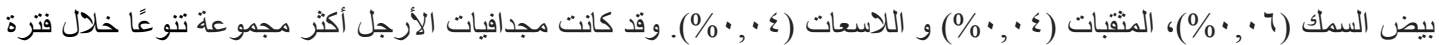

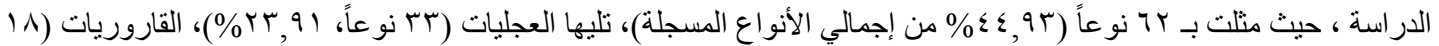

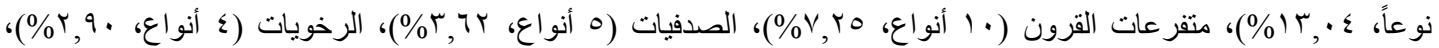

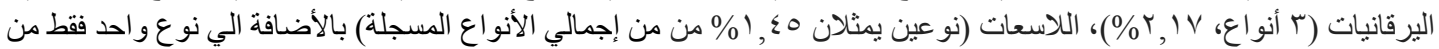

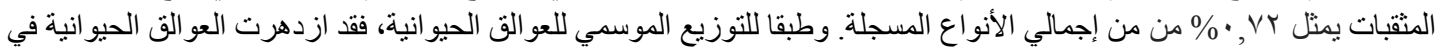

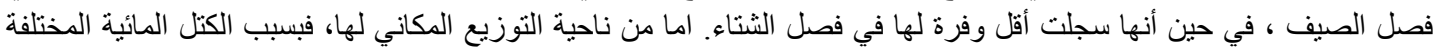

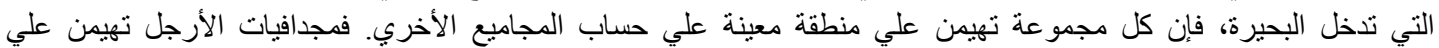

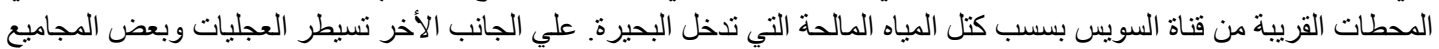
الأخري علي المحطات القريية من كتل المياه العذبة التي تدخل البحيرة بقرب البئ البحيرة الغربية. 